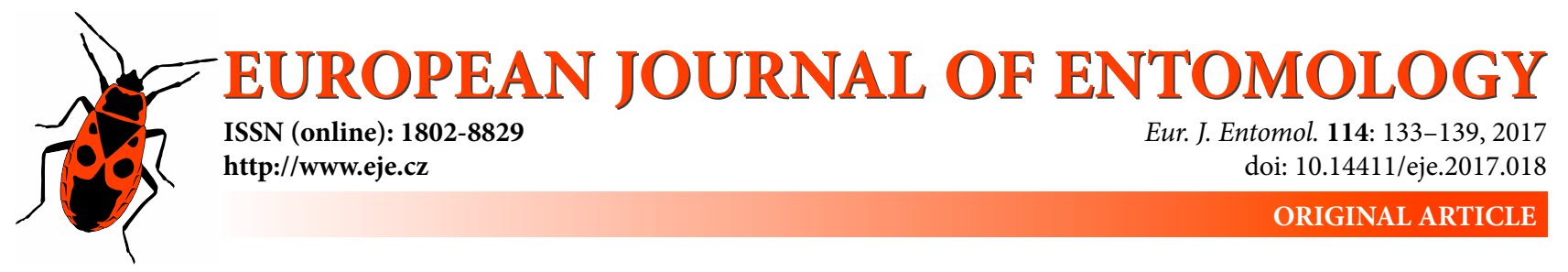

\title{
Adaptive significance of the prolonged diapause in the western Mediterranean lycaenid butterfly Tomares ballus (Lepidoptera: Lycaenidae)
}

\author{
Rafael OBREgón, JuAn FERNÁNDEZ HAEGER and Diego JORDANO \\ Department of Botany, Ecology and Plant Physiology, University of Córdoba, E-14071, Córdoba, Spain; \\ e-mails: rafaobregonr@gmail.com, bv1fehaj@uco.es, bv1jobad@uco.es
}

Key words. Lepidoptera, Lycaenidae, Tomares ballus, prolonged diapause, evolutive adaptation, changing environment, competition, parasitoids

\begin{abstract}
Diapause is a common dormancy strategy exhibited by many species of invertebrates and insects to temporarily avoid seasonally recurring unfavourable conditions for their development, most usually in winter. Less frequently, a prolonged diapause lasting two or more years is described in species living in unpredictable environments where it is adaptive, but with significant costs. In this paper we examine the occurrence of prolonged diapause in the lycaenid butterfly Tomares ballus. Pupae of this species undergo an obligate diapause from mid-May to late January the following year. However, during our rearing experiments (from 2009 to 2016) the emergence of adults occurred sequentially and a fraction of the pupae remained in diapause for up to seven years. The annual percentage emergence after the first year of diapause was $45.6 \%$, and only barely exceeded $50.0 \%$ in 2015. Remarkably, 12 pupae ( $11.4 \%$ of the initial brood) remained in diapause in their eighth year. The negative exponential equation fitted to the emergence data suggests that further emergences may occur within the next five years. Therefore, the potential for successful prolonged diapause of $T$. ballus pupae may be more than 10 years. The adaptive value of this strategy is discussed in relation to the effects of adverse and unpredictable weather during the flight period of the butterfly, intra-guild competition, parasitoids and changes in habitat quality. We suggest that this strategy may also be exhibited by other species of Mediterranean lycaenids.
\end{abstract}

\section{INTRODUCTION}

Diapause, a state of arrested development, is the major strategy for surviving seasonally unfavourable environmental conditions (Ellers \& Van Alphen, 2002). Associated with changes in environmental conditions, growth or development is suspended and physiological activity diminished. Diapause is a common strategy in many invertebrates and among insects, especially in temperate regions. It is also common in butterflies and may occur at any stage in their life cycles (Danks, 1987).

Photoperiod is the most reliable cue of seasonal change and also the most important stimulus initiating diapause (Danilevskii, 1965; Sakamoto et al., 2015), although changes in temperature and host plant quality may also play a role, especially in species with facultative diapause (Kurban et al., 2007; Sakamoto et al., 2015). The critical day length at which $50 \%$ of the individuals of a population enter diapause is genetically determined (Danilevskii, 1965) and therefore in temperate regions most of them enter diapause at the beginning of autumn. In Mediterranean areas winter diapause (hibernation) is a quite common strategy for avoiding unfavorable winter conditions, but also in this area, hot and dry summers, with some species additionally exhibiting a pronounced summer diapause (aestivation) in response to increase in day length (Held \& Spieth, 1999; Sands \& New, 2008; Sakamoto et al., 2015).

Environmental and hormonal regulators of diapause are reasonably well defined (Templado, 1981; Denlinger, 2002; Zhang et al., 2004, 2008), but less so the molecular regulation of diapause (Xu et al., 1995; Denlinger, 2002).

A prolonged diapause lasting more than a year, also called extended diapause, is described in several species of insects (Danks, 1987), especially Lepidoptera (Powell, 1986). For instance, in the most extreme case to date, fully grown larvae of the moth Prodoxus y-inversus Riley, 1892 (Lepidoptera: Prodoxidae) can remain in diapause for up to 30 years under controlled conditions (Powell, 2001). The physiological mechanisms of prolonged diapause are not well understood (Tauber et al., 1986), although chilling temperatures may play a key role as token stimuli for diapause termination (Powell, 1989, 2001). In Lepidoptera, the adaptive value of a prolonged diapause may be high in fluctuating, unpredictable environments where the avail- 
able resources are limited in time and/or undergo erratic fluctuations (Sunose, 1978).

Powell (1986) recognized two types of extended diapause: (a) in response to adverse conditions and (b) genetically determined, while Hanski (1988) differentiated between density-independent and density-dependent prolonged diapause.

The occurrence of prolonged diapause is recorded for species of Lepidoptera belonging to the families Prodoxidae, Saturniidae, Geometridae, Noctuidae, Tineidae, Coleophoridae, Gelechiidae, Ethmiidae, Tortricidae, Cochylidae, Lasiocampidae, Sphingidae, Notodontidae, Pyralidae, Pieridae, Papilionidae and Lycaenidae (Nakamura \& Ae, 1977; Powell, 1986; Benyamini, 2008).

In this paper we examine the occurrence of facultative prolonged diapause in the Provence hairstreak Tomares ballus (Fabricius, 1787). This Lycaenid is a Western Mediterranean endemic species occurring in the Maghreb and on the Iberian Peninsula, with disjunct populations in south-eastern France (Descimon, 1990, 1992), where it occurs in grassland and early successional-stage habitats (Jordano et al., 1990b). In the Sierra Morena mountains (southern Spain) this univoltine lycaenid species has an early flight period from late January to late April, peaking in mid March. Diapause occurs during the pupal stage and lasts around nine months, (Jordano et al., 1990a). In the Sierra Morena T. ballus larvae feed on flowers and seeds of Erophaca baetica (L.) Boiss., a perennial legume that grows in disturbed habitats and is toxic to vertebrate herbivores (Jordano et al., 1990a). This species is also a host plant of Lampides boeticus (L.) and Leptotes pirithous (L.), two generalist multivoltine and migrant lycaenid butterflies. Eggs and larvae of the three species are often found on the same inflorescences and T. ballus appears to be competitively inferior to the other two species (unpubl. data).

Given the highly fluctuating but generally adverse weather conditions during the early flight period of $T$. bal$l u s$, as well as the spatiotemporal variability in the adverse effects of inter specific competition with L. boeticus (also L. pirithous, to a lesser extent) and in parasitoid attacks [Cotesia astrarches (Marshall, 1889), C. inducta (Papp, 1973) and C. specularis (Szepligeti, 1896) (Hymenoptera: Braconidae)] (Obregón et al., 2015), we hypothesized that pupae of T. ballus undergo an extended diapause as a strategy for spreading the risk of reproductive failure over years. We conducted a study on the duration of diapause in a cohort of T. ballus pupae reared in the laboratory as part of a broader study on the ecological interactions in a guild of lycaenids (Obregón et al., 2012, 2015).

\section{METHODS}

\section{Butterfly phenology and flight period}

Data on the phenology of the lycaenid species were gathered from 2009 to 2014 in different patches of E. baetica in the Sierra Morena (Andalusia, southern Spain). More details of the study area are given in Jordano et al. (1990a, b). Patches were visited at least six times per year during this period and butterflies in each patch were counted along transects at a fixed time. The flight period was determined by plotting the observed number of butterflies against the Julian date.

\section{Minimum temperature threshold needed for flight}

To estimate the minimum temperature threshold needed for flight we conducted a simple experiment. For this purpose, 16 newly emerged butterflies (10 males, 6 females) were tested independently, placed in the sun early in the morning and left undisturbed, and the time they flew off was recorded. The butterflies were then captured and allowed to cool, and subsequently retested in the shade. We used a data logger to record temperature at $30 \mathrm{~s}$ intervals during the whole experiment, which allowed us to compare temperatures at which each butterfly started to fly when exposed to sun or in shade. The mean of temperatures at which the butterflies flew was taken as the minimum threshold temperature for adult activity. Maximum temperatures during the two days of the experiment were 16 and $17^{\circ} \mathrm{C}$, respectively.

\section{Weather constraints during the flight period}

Activity and realized fecundity of butterflies could be significantly reduced by adverse weather conditions during the flight period, and therefore we analyzed a temporal series of meteorological data from 2001 to 2015 , recorded by the weather station at Villaviciosa de Córdoba (latitude $38^{\circ} \mathrm{N}$, longitude $5^{\circ} \mathrm{W}$; altitude: $600 \mathrm{~m}$ a.s.1.), which is the closest to the study area. The meteorological interval studied within each year was the 15 to $105 \mathrm{Ju}$ lian days, corresponding to the flight period of this species. More precisely, we compared daily mean and maximum temperatures with the minimum threshold for adult activity and also the number of rainy days during the flight period. We then estimated the frequency of days on which weather conditions presumably prevented or severely limited the activity of the butterflies.

\section{Diapause duration}

Third instar larvae of T. ballus were collected in the field and subsequently transferred to plastic containers in the laboratory. Larvae, fed ad libitum on E. baetica inflorescences and fruits, were kept at ambient temperature and natural day length. The rearing containers were cleaned and fresh food supplied to the larvae each day. Containers were checked daily to record dates of pupation. In the field T. ballus larvae do not pupate on the host plant. In the laboratory fully grown larvae usually spend two or even three days crawling around the containers without feeding. This behaviour indicates that in the field they can move a considerable distance searching for a suitable pupation site in the ground, presumably inside an ant's nest. In fact, it is known that the larvae are not attacked by ants when introduced into artificial nests of Cataglyphis hispanica (Emery, 1906) and Tapinoma nigerrimum (Nylander, 1856) (Jordano et al., 1990b; Kan et al., 2010).

A total of 149 diapausing pupae were moved from the laboratory to a large shed in the countryside, outside the city, where they were kept from 2009 to 2016 . The shed was covered by old corrugated fiber cement roofing and lacked insulation. Therefore, the indoor temperatures experienced by the pupae were approximately similar to the ambient temperature outside, especially during winter. The main differences were higher indoor temperatures during summer (roughly up to $+3^{\circ} \mathrm{C}$ ) and protection from rain. The pupae were protected from rain throughout the experiment, which may have had some effect on the end of diapause, but this effect is unknown. In any case, all pupae were maintained in the same conditions.

During the following years the pupae were checked daily from late January onwards, recording the date of emergence of each adult butterfly. The newly emerged butterflies were subsequently released in the patches where they were collected as larvae. 


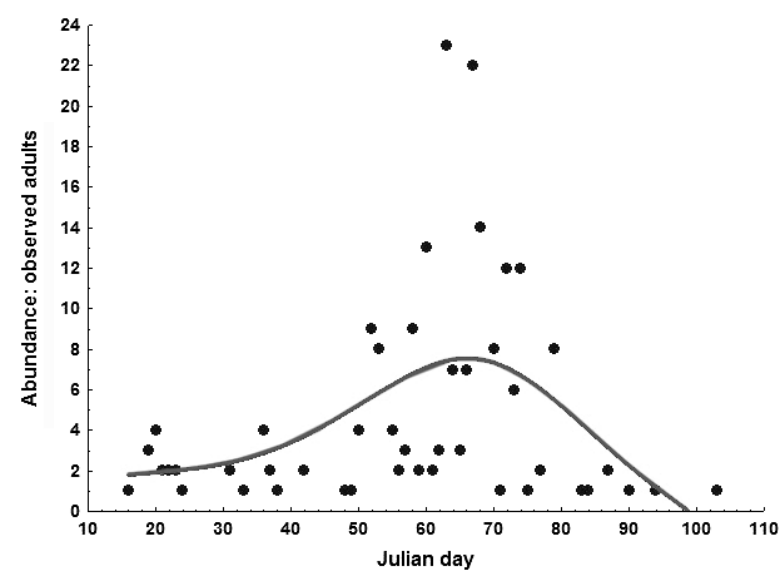

Fig. 1. Relative abundance of adults of the Provence Hairstreak (Tomares ballus) recorded in the field over the course of a year (Julian days) in the period 2009-2014 in the Sierra Morena Mountains (Andalusia, S. Spain).

\section{RESULTS}

\section{Phenology, flight period and minimum temperature threshold for flight}

The Provence Hairstreak flies from late January to midApril, with a peak in their abundance on the $65^{\text {th }}$ Julian day (Fig. 1). Approximately $90 \%$ of the observations were made between the $50^{\text {th }}$ and $80^{\text {th }}$ Julian days (late February to end of March). The estimated minimum ambient temperature threshold for flight was $14.4^{\circ} \mathrm{C}$ (Table 1). Below $14^{\circ} \mathrm{C}$ the butterflies remained inactive, while the optimum temperature ranged between 17 and $24^{\circ} \mathrm{C}$.

Table 1. Minimum temperature $\left({ }^{\circ} \mathrm{C}\right)$ at which $T$. ballus flew in direct sunshine and shade. Mean values and standard deviations are presented ( $n=16$ individuals). Solar hour: 8-10.30 AM.

\begin{tabular}{lcc}
\hline \multirow{2}{*}{ Exposure } & \multicolumn{2}{c}{ Minimum flight temperature $\left({ }^{\circ} \mathrm{C}\right)$} \\
\cline { 2 - 3 } & Day 1 & Day 2 \\
\hline Shade & $14.1 \pm 0.9$ & $14.7 \pm 0.7$ \\
Direct sun & $11.8 \pm 0.5$ & $11.9 \pm 0.6$ \\
\hline
\end{tabular}

In shade, males flew at a lower ambient temperature $\left(14.3 \pm 0.59^{\circ} \mathrm{C} ; \mathrm{n}=11\right)$ than females $\left(15.2 \pm 0.40^{\circ} \mathrm{C} ; \mathrm{n}=\right.$ 5 ) and exposed to sun males also flew at a lower ambient temperature $\left(11.5 \pm 0.62^{\circ} \mathrm{C} ; \mathrm{n}=11\right)$ than females $(12.0 \pm$ $\left.0.51{ }^{\circ} \mathrm{C} ; \mathrm{n}=5\right)$. The differences in temperatures at which males and females flew in both shade and direct sun are significant (GLM nested; $P<0.001$ ).

These results indicate that the butterflies can be active and fly when the air temperature is around $2-3^{\circ} \mathrm{C}$ lower

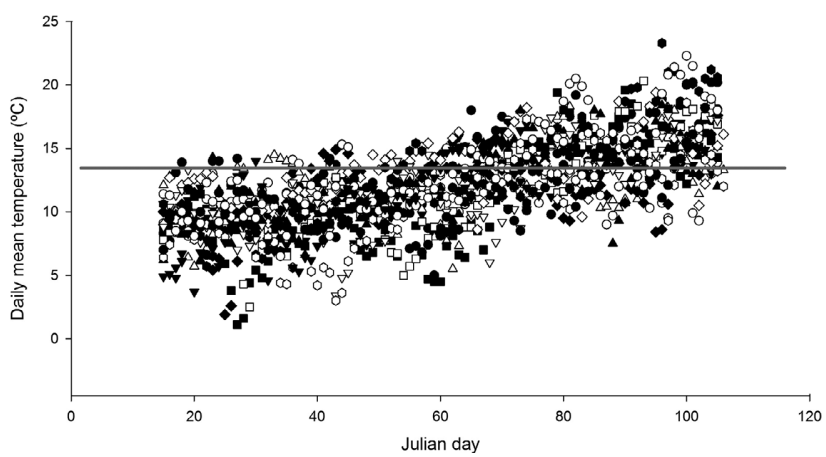

Fig. 2. Daily mean temperatures recorded over the course of a year for the 15 years $(2001-2015)$. The red line is the $14^{\circ} \mathrm{C}$ threshold.

than the minimum threshold if they can warm up by basking in the sun. T. ballus uses lateral basking, with their wings folded and angled at $90^{\circ}$ to the sun.

\section{Weather constraints during the flight period}

The daily mean temperature showed a consistent increase from the onset to the end of the flight period throughout the period of the study (2001-2015), but on most days it was lower than the minimum temperature threshold for flight (Fig. 2). In fact, the fraction of days per flight season in which the mean temperature was higher than the minimum threshold ranged from 0.11 to 0.29 during this study. There was a noticeable variation in temperature and number of rainy days among years, as shown in Fig. 3. Overall, for the whole period (15-105 Julian days; 15 years; $n=1353$ days) the mean fraction of days with a mean temperature higher than $14.4^{\circ} \mathrm{C}$ and therefore suitable for flight was 0.21 (s.d. $=0.06 ; \mathrm{n}=396$ ). On days with a mean temperature lower than the minimum threshold, it could be reached or even exceeded by the butterflies, at least during short clear spells around noon, basking in the sun. The fraction of days in the flight season when the maximum temperature was higher than the minimum threshold that was around 0.62 on average (Fig. 3). On the other hand, rain during the flight season of T. ballus occurred on up to $40 \%$ of the available days (Fig. 3). The mean frequency of rainy days during the flight season (from 2001-2015) was 0.28 (s.d. $=0.09 ; \mathrm{n}=$ 545). In fact, March is on average the rainiest month of the year in the study area. Taking the range of 30 Julian days when $90 \%$ of the butterfly data were recorded (2001-2015 time series), on average the fraction of days in which either the daily temperature was lower than the minimum threshold or rainfall was greater than $2 \mathrm{~mm}$ was 0.74 (s.d. $=0.13$; $n=334$ ). As a consequence, during the flight period of this

Table 2. Prolonged pupal diapause and delayed emergence in a cohort of $149 \mathrm{~T}$. ballus butterflies.

\begin{tabular}{lccccccc}
\hline Year & $\begin{array}{c}\text { Emerged } \\
\text { adults }\end{array}$ & $\begin{array}{c}\text { Cumulated } \\
\text { no. adults }\end{array}$ & $\begin{array}{c}\text { Remaining } \\
\text { pupae }\end{array}$ & $\begin{array}{c}\text { Percentage } \\
\text { emergence }(\%)\end{array}$ & $\begin{array}{c}\text { Emergence } \\
\text { interval }\end{array}$ & $\begin{array}{c}\text { Mean } \\
\text { emerge days }\end{array}$ & $\begin{array}{c}\text { Years in } \\
\text { diapause }\end{array}$ \\
\hline 2010 & 68 & 68 & 81 & 45.6 & 19 Feb.-11 Mar. & $320.2 \pm 5.5$ & 1 \\
2011 & 22 & 90 & 59 & 27.2 & 28 Feb.-22 Mar. & $701.9 \pm 5.7$ & 2 \\
2012 & 9 & 99 & 50 & 15.3 & 7 Feb.-14 Mar. & $1041.2 \pm 14.7$ & 3 \\
2013 & 14 & 113 & 36 & 28.0 & $9-19$ Feb. & $1402.1 \pm 4.5$ & 4 \\
2014 & 1 & 114 & 35 & 2.8 & 14 Feb. & $1769.0 \pm 0.0$ & 5 \\
2015 & 18 & 132 & 17 & 51.4 & $12-16$ Mar. & $2162.6 \pm 2.5$ & 6 \\
2016 & 7 & 139 & 10 & 41.2 & $8-16$ Feb. & $2496.4 \pm 5.4$ & 7 \\
\hline
\end{tabular}




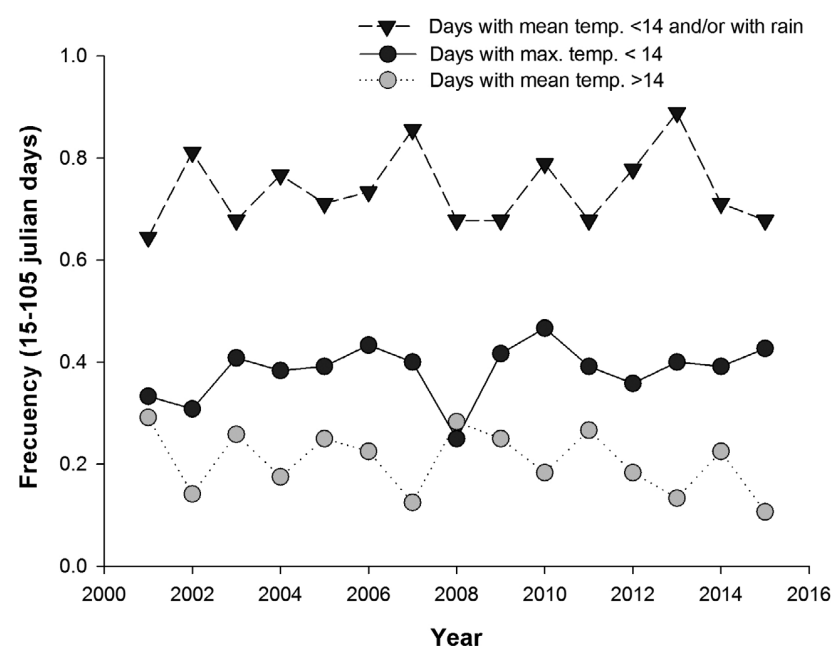

Fig. 3. Frequency of days with a maximum temperature below $14^{\circ} \mathrm{C}$, with a mean temperature above $14^{\circ} \mathrm{C}$ and with a mean temperature below $14^{\circ} \mathrm{C}$ and/or with rain (above $2 \mathrm{~mm}$ ) for the 15-105 Julian days (2001-2015).

lycaenid most days were unfavorable for normal activity (feeding, mating, egg laying, etc), which is likely to have an adverse effect on their reproductive success.

\section{Prolonged diapause}

The emergence of butterflies from the 149 pupae reared in the laboratory in 2009 was monitored annually from 2010 to 2016, and the main results are summarized in Table 2.

Remarkably, 12 pupae ( $11.4 \%$ of the initial brood) remained in diapause in their eighth year. The annual percentage emergence after the first year of diapause was $45.6 \%$, and only barely exceeded $50.0 \%$ in 2015 .

The results of a survival analysis applied to the emergence data are summarized in the plot of the survival function obtained using the Kaplan-Meier estimator (Fig. 4). The number of pupae remaining in diapause over time is well described by an exponential decay function (Fig. 5), which indicates that some pupae could remain in diapause for approximately six more years, i.e., until 2022.

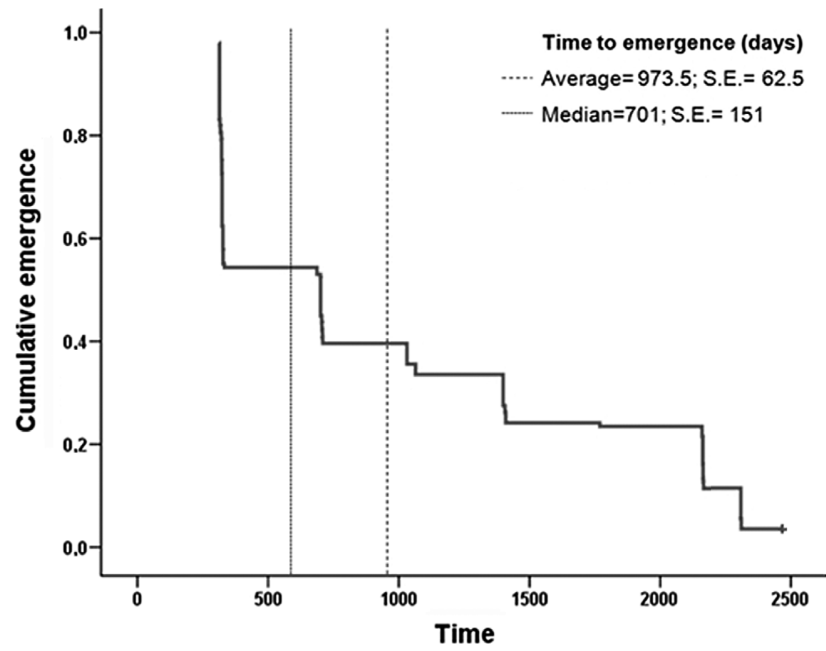

Fig. 4. Plot of the Kaplan-Meier survival function applied to the data of adult emergences. The time in days spent in diapause is shown on the $x$ axis.

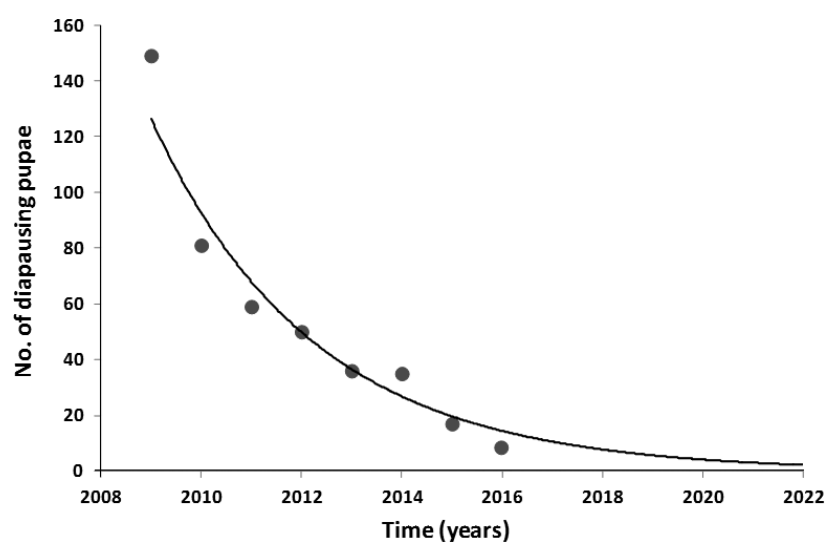

Fig. 5. Plot of the negative exponential regression between number of pupae remaining in diapause and time $\left(y=5 E+272^{e-0.31 x} ; R^{2}\right.$ $=0.9447)$. The regression equation is highly significant $(p<0.01)$.

\section{DISCUSSION}

Diapause is a neuro-hormonally mediated state in an organism's life cycle when development, growth and/or reproduction may temporarily cease when environmental conditions are unfavourable (Tauber et al., 1986). It is a common adaptive trait in obligate univoltine insects, enabling them to survive recurring periods of temperature extremes and/or food shortage (Andreawartha, 1952). Diapause can also be a trait of species that are rapidly spreading if the level of environmental stochasticity is high (Mahdjoub \& Menu, 2008). However, some insect species can extend diapause for more than one year under suboptimal weather conditions (Powell, 1986). The most extreme case reported to date is that of Yucca moth larvae remaining in diapause for up to 30 years (Powell, 2001) or that of the typical desert pierid Euchloe falloui of up to 15 years (Benyamini, 2008).

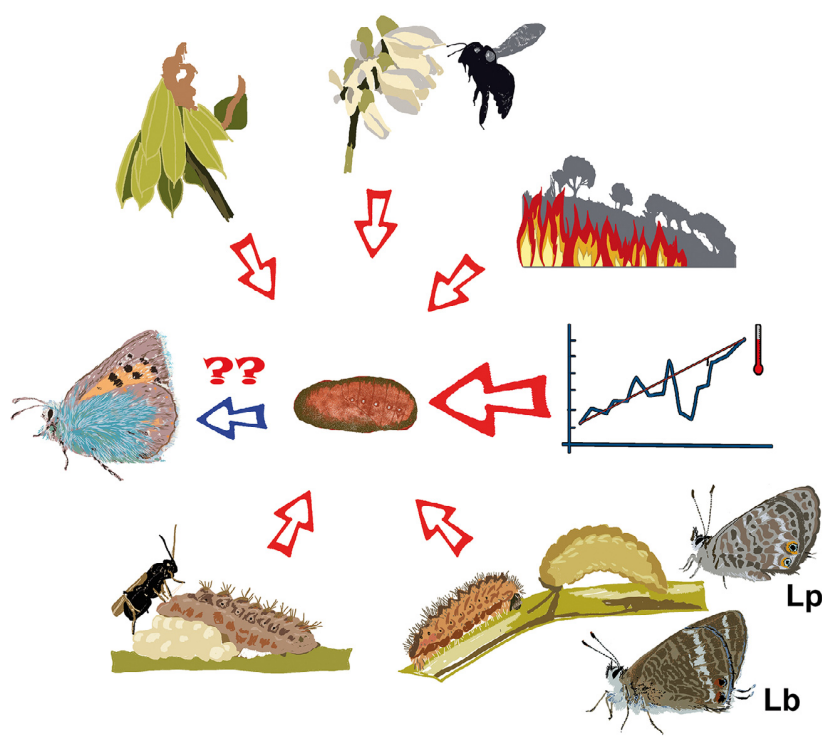

Fig. 6. The prolonged diapause in $T$. ballus is mainly seen as an adaptation to harsh and unpredictable climatic conditions during its early flight period. However, it may also reduce the negative effects of the extreme events that occur in some years, like unusually high seed abortion resulting in a food shortage for the larvae, unusually high parasitism and/or competition with $L$. boeticus (Lb) and $L$. pirithous (Lp) (opportunistic migrants), or an habitat perturbation. 
The facultative extended diapause is frequently recorded in species living in habitats with harsh conditions and ephemeral, highly unpredictable resources, which indicate it is adaptive (Danks, 1987). Spreading the risk by within population variation in the length of the pupal phase is interpreted as a bet-hedging strategy evolved to cope with the risk of uncertainty (Rajon et al., 2014; Ratcliff et al., 2015). Here we document the occurrence of a facultative extended diapause in the butterfly $T$. ballus. Diapause in pupae reared in 2009 extended to the seventh year after pupation (2015), with $54.4 \%$ of the pupae remaining in prolonged diapause for 2 to 7 years, and 10 pupae still in diapause in the eighth year. This species has some of the features pointed out by Powell (1986) for species that remain in diapause for a prolonged period of time: (a) diapause occurs in the pupal stage; (b) seed-eating species that depend on seasonal fruit crops.

Compared with other butterfly species, the flight period of T. ballus is exceptionally early in the year (Fernández Haeger \& Jordano, 1982; Obregón \& Prunier, 2014) and coincides with the cold and rainy season in Mediterranean climates. In this period the weather is highly unpredictable and the combined effect of low temperatures, cloudy skies and rain may have a dramatic effect on the activity of butterflies and their reproductive success and, as a consequence, on the persistence of populations. Our results indicate that a result of not being able to bask in the sun, is that on average the minimum threshold temperature for flying is $14.4^{\circ} \mathrm{C}$ and slightly lower for males than for females (statistically significant; $P<0.001$ ). This difference can probably be explained because males have to find and defend the best territories for reproduction, as occurs in other perching species of Lepidoptera (Wiklund, 2003; Bergman et al., 2007).

Analysis of a meteorological time series data extending from 2001 to 2015, indicate that frequent low temperatures combined with cloudy skies and rain may have largely constrained the activity of the butterflies. In years with extreme conditions, the time constraints for feeding, mating and oviposition may have had a dramatic effect on their reproductive success. For example, in 2010 the recorded rainfall was almost double the average, and both average and maximum temperatures during the flight period of $T$. ballus were very often below the minimum threshold for flight. Under these circumstances, the ability to undergo a prolonged diapause may play a key role in determining the persistence of populations at both local and regional scales. These results are in agreement with theory, which predicts that spreading the risk by phenotypic diversification is strongly favoured when the risk faced has a wide spatial extent with a single disaster affecting a large fraction of the population, or in small populations subject to frequent disasters (Ratcliff et al., 2015).

In the fruit fly Rhagoletis cerasi (Diptera: Tephritidae), both insufficient and extended exposure to chilling promote prolonged and facultative dormancy, respectively (Moraiti et al., 2014). In our experiment however, these factors can be ruled out as determinants of the prolonged diapause recorded for more than half of the pupae. Exposure to exactly the same temperature and humidity conditions elicited very different responses among the pupae in terms of diapause termination.

The highly significant negative exponential equation fitted to the emergence data indicates that further emergences may occur over the next five years (Fig. 5). Therefore, the potential for successful extended diapause of T. ballus pupae may be more than 10 years.

The ecological and evolutionary significance of prolonged diapause has been studied in desert bees (Danforth, 1999), which show a striking parallelism with desert annual plants with long lasting dormant seeds. The extended diapause in bees and seed dormancy in annual plants is interpreted as bet-hedging strategies for spreading the risk in harsh and unpredictable varying environments (Danforth 1999; Tielbörger et al., 2012). In the case of T. ballus, a prolonged diapause may prove to be a valuable adaptation that evolved due to the highly variable and unpredictable weather conditions during its exceptionally early flight period. In addition, a prolonged diapause might also help reduce the negative effect of other rare events on butterfly demography. For example, major seed abortion by plants due to bad weather and/or nectar robbers [Xylocopa violacea L. and Bombus spp. Latreille, 1802 (Apidae)] that destroy a high proportion of the reproductive investment of $E$. baetica can result in a severe shortage of available resources for its larvae (Jordano et al., 1990a, b). In addition, percentage parasitism due parasitoids (C. astrarches, C. inducta and C. specularis) (Obregón et al., 2015), may vary greatly $(16.7-80.3 \% ; n=653$; unpubl. data) among patches and years. On the other hand, eggs and larvae of $T$. ballus are frequently found on the same inflorescences of E. baetica as the migrant generalist competitors $L$. boeticus and L. pirithous. Although egg laying by T. ballus occurs earlier, its larval development time $(52.5 \pm 2.1$ days; $\mathrm{n}=$ 42 ) is much longer than in the other two species (L. boeticus $=17.1 \pm 1.5$ days; $\mathrm{n}=59 ;$ L . pirithous $15.6 \pm 1.1$ days; $n=59$ ) (Obregón, 2015). As a consequence, the wide temporal overlap between larval stages in this guild of species facilitates competitive interactions. The final effect of competition between larvae in this guild of species is strongly asymmetric for the Provence hairstreak because, in most cases, their larvae are attacked and preyed upon by the other two species (Obregón et al., 2012). This kind of interaction may be especially intense when the local abundances of L. pirithous and L. boeticus are increased by the arrival of migrants. Finally, forest fires and other unpredictable habitat perturbations might produce different dramatic effects. Under such scenarios, extending diapause (a prolonged diapause) may increase survival and reproductive success, and hence the persistence of local populations (Fig. 6).

In the fruit fly $R$. cerasi diapause duration is determined by both adaptation to local climatic conditions and phenotypic plasticity in response to inter-annual climatic variability (Moraiti et al., 2014). In the case of T. ballus, the factors determining diapause termination remain un- 
known. Due to the high variability in diapause duration recorded among the pupae, despite being exposed to the same climatic conditions, temperature, photoperiod and/or humidity do not appear to be the cues triggering diapause termination, as reported for other species (Templado, 1981; Powell, 2001; Moraiti et al., 2014; Sakamoto et al., 2015).

In the desert bee Perdita portalis (Andrenidae) only approximately half of the larvae pupate under optimal conditions and those with a high body weight are more likely to undergo prolonged diapause than larvae with a low body weight (Danforth, 1999). The same pattern has been reported for the fruit fly $R$. cerasi, in which there is a tradeoff between prolonged diapause and lifetime fecundity and oviposition (Moraiti et al., 2012). We did not weigh the pupae and therefore do not know whether there is a relation between prolonged diapause and pupal weight.

Other butterfly species belonging to the families Pieridae, Papilionidae and Lycaenidae that live in unfavourable environmental conditions, like deserts, have the same bethedging strategy. Pierids living in deserts, such as Euchloe falloui, undergo a prolonged diapause ranging from one to fifteen years (Benyamini, 2008). Papers on prolonged diapause in other Lycaenidae species are scarce (Pratt \& Balmer, 1986). Benyamini (1999, 2008) describes prolonged diapause in pupae of the Eastern-Mediterranean lycaenid Iolana alfierii (3 years), Pseudophilotes abencerragus nabataeus (4 years), $P$. jordanicus (3 years) and Tomares nesimachus (3 years). Also, Gil-T. (2004) and Muñoz Sariot (2011) document a 2 year-long diapause in $I$. debilitata living in the southern part of the Iberian Peninsula. The life history of I. debilitata has some similarities with T. ballus. Both species feed on seeds inside legume pods and interact with the opportunistic L. boeticus and occasionally with $L$. pirithous. These interactions include interspecific competition and cannibalism (Gil-T., 2004; Muñoz Sariot, 2011).

We presume that this type of bet-hedging strategy may also be exhibited by other species of Lycaenidae, in particular some other Mediterranean species that must cope with harsh and unpredictable conditions. For example, we can also confirm the occurrence of a prolonged diapause in the Iberian-North African lycaenid Pseudophilotes abencerragus and the Pierid Zegris eupheme, whose pupae can remain in diapause for at least three years (unpubl. data).

Finally, the Provence hairstreak is assigned the Least Concern (LC) status in the Red List of European Butterflies (Van Swaay et al., 2010). It is more abundant in Spain than in southern France (Thomas \& Mallorie, 1985). Nevertheless some efforts should be made to conserve this Lycaenid, which has a very restricted distribution in Europe. Based on our experience, real estate development in coastal areas, abandonment of inland marginal lands and pesticides are the main causal factors of the decline in T. ballus in southern Spain. Currently, perhaps the most effective strategy for conserving the habitat of T. ballus would be to inform private landowners about the requirements of this species (Descimon, 1990). Such efforts could result in a continuation of the traditional management of the Mediter- ranean landscape and an adequate proportion of grassland and shrubs in extensive pasturelands.

ACKNOWLEDGEMENTS. We are grateful to S. Mañas Lezameta for designing the Fig. 6, to S. de Haro for helping with the field work and the laboratory experiment in 2009 . We wish to express our appreciation to the editor and three anonymous reviewers for their insightful comments and suggestions, which have greatly improved this manuscript.

\section{REFERENCES}

ANDREAWARTHA H.G. 1952: Diapause in relation to the ecology of insects. - Biol. Rev. 27: 50-107.

BENYAMINI D. 1999: The biology and conservation of Iolana alfierii Wiltshire, 1948: The Burning Bush Blue (Lepidoptera: Lycaenidae). - Linneana Belg. 17: 119-134.

BenYamini D. 2008: Is Euchloe falloui Allard, 1867 (Pieridae) the butterfly with the longest diapause? - Nota Lepid. 31: 293-295.

Bergman M., Gotthard K., Berger D., Olofsson M., Kemp D.J. \& WIKLUND C. 2007: Mating success of resident versus nonresident males in a territorial butterfly. - Proc. R. Soc. Lond. (B) 274: 1659-1665.

DANILEVSKII A.S. 1965: Photoperiodism and Seasonal Development of Insects. Oliver and Boyd, Edinburgh, $283 \mathrm{pp}$.

DANFORTH B.N. 1999: Emergence dynamics and bet hedging in a desert bee, Perdita portalis. - Proc. R. Soc. Lond. (B) 266 : 1985-1994.

Danks H.V. 1987: Insect Dormancy: An Ecological Perspective. Biological Survey of Canada, Ottawa, $439 \mathrm{pp}$.

DenLinger D.L. 2002: Regulation of diapause. - Annu. Rev. Entomol. 47: 93-122.

Descimon H.A. 1990: Pourquoi y a-t-il moins de papillons aujourd'hui? - Insectes 77: 6-10.

Descimon H.A. 1992: Le faux-cuivre smaragdin, Tomares ballus F. In New T.R. (ed.): Conservation Biology of Lycaenidae (Butterflies). IUCN Species Survival Commission, Gland, 184 pp.

Ellers J. \& Van Alphen J.J.M. 2002: A trade-off between diapause duration and fitness in female parasitoids. - Ecol. Entomol. 27: 279-284.

Fernández Haeger J. \& Jordano D. 1982: Fenología de una comunidad mediterránea de mariposas diurnas. - Biol. Ecol. Mediterran. 9: 19-28.

GIL-T. F. 2004: Nuevos datos sobre la biología de Iolana iolas Ochsenheimer (Lepidoptera, Lycaenidae) y su interacción con himenópteros mirmecófilos, fitófagos y parasitoides (Hymenoptera, Formicidae, Eurytomidae, Ichneumonoidea). - Bol. Soc. Entomol. Aragon. 34: 139-145.

HANSKI I. 1988: Four kinds of extra long diapause in insects: A review of theory and observations. - Ann. Zool. Fenn. 25: $37-53$.

Held C. \& Spieth H.R. 1999: First evidence of pupal summer diapause in Pieris brassicae L.: the evolution of local adaptedness. - J. Insect Physiol. 45: 587-598.

Jordano D., Fernández Haeger J. \& Rodríguez J. 1990a: The life-history of Tomares ballus (Fabricius, 1787) (Lep.: Lycaenidae): phenology and host plant use in southern Spain. $-J$. Res. Lepid. 28: 112-122

Jordano D., Fernández Haeger J. \& Rodríguez J. 1990b: The effect of seed predation by Tomares ballus (Lepidoptera: Lycaenidae) on Astragalus lusitanicus (Fabaceae): determinants of differences among patches.-Oikos 57: 250-256. 
Kan P., Kan-van Limburg Stirum B. \& Bertaud P. 2010: Contribution à la connaissance de Tomares ballus (Fabricius, 1787) (Lepidoptera: Lycaenidae). — Rev. Lépidopt. Fr. 19: 60-74.

Kurban A., Yoshida H., Izumi Y., Sonoda S. \& Tsumuki H. 2007: Pupal diapause of Helicoverpa armigera (Lepidoptera: Noctuidae): sensitive stage for thermal induction in the Okayama (western Japan) population. - Bull. Entomol. Res. 97: 219223.

Mahdjoub T. \& Menu F. 2008: Prolonged diapause: a trait increasing invasion speed? - J. Theor. Biol. 251: 317-330.

Moraiti C.A., NaKas C.T. \& Papadopoulos N.T. 2012: Prolonged pupal dormancy is associated with significant fitness cost for adults of Rhagoletis cerasi (Diptera: Tephritidae). - J. Insect Physiol. 58: 1128-1135.

Moraiti C.A., Nakas C.T. \& Papadopoulos N.T. 2014: Diapause termination of Rhagoletis cerasi pupae is regulated by local adaptation and phenotypic plasticity: Escape in time through bet-hedging strategies. - J. Evol. Biol. 27: 43-54.

MuÑoz SARIOT M.G. 2011: Biología y Ecología de los Licénidos Españoles. M.G. Muñoz Sariot, Granada, 265 pp.

NaKamura I. \& Ae S.A. 1977: Prolonged pupal diapause of Papilio alexanor: arid zone adaptation directed by larval host plant. - Ann. Entomol. Soc. Am. 70: 481-484.

OBREGÓN R. 2015: Interacciones Ecológicas y Modelos de Distribución Actual y Futura de Lepidópteros en Andalucía. PhD Thesis, Universidad de Córdoba, 232 pp.

Obregón R. \& Prunier F. 2014: Diversidad y ecología de una comunidad de ropalóceros (Lepidóptera) en el arroyo Pedroches y su entorno: Un paraje natural periurbano a conservar (Córdoba, España). — Rev. Gad. Entomol. 5: 183-201.

Obregón R., de Haro S., Jordano D. \& Fernández Haeger J. 2012: Lampides boeticus (Lepidoptera: Lycaenidae) preys on cocoons of its own specific parasitoid Cotesia specularis (Hymenoptera: Braconidae). - J. Insect Behav. 25: 514-517.

Obregón R., Shaw M.R., Fernández Haeger J. \& Jordano D. 2015: Parasitoid and ant interactions of some Iberian butterflies (Insecta: Lepidoptera). — SHILAP Revta Lepid. 43: 439-454.

Powell J.A. 1986: Records of prolonged diapause in Lepidoptera. - J. Res. Lepid. 25: 83-109.

Powell J.A. 1989: Synchronized, mass-emergences of a yucca moth, Prodoxus y-inversus (Lepidoptera: Prodoxidae), after 16 and 17 years in diapause. - Oecologia 81: 490-493.

Powell J.A. 2001: Longest insect dormancy: Yucca moth larvae (Lepidoptera: Prodoxidae) metamorphose after 20, 25, and 30 years in diapause. - Ann. Entomol. Soc. Am. 94: 677-680.

Pratt G.F. \& Ballmer G.R. 1986: The phenetics and comparative biology of Euphilotes enoptes (Boisduval) (Lycaenidae) from the San Bernardino Mountains. - J. Res. Lepid. 25: 121-135.

Rajon E., Desouhant E., Chevalier M., Débias F. \& Menu F. 2014: The evolution of bet hedging in response to local ecological conditions. - Am. Nat. 184: 1-15.
Ratcliff W.C., Hawthorne P. \& Libby E. 2015: Courting disaster: How diversification rate affects fitness under risk. - Evolution 69: 126-135.

SAKAmoto Y., Hirai N. \& IshiI M. 2015: Effects of photoperiod and temperature on the development and diapause of the endangered butterfly Zizina emelina (Lepidoptera: Lycaenidae). - J. Insect Conserv. 19: 639-645.

SAnDS D.P.A. \& New T.R. 2008: Irregular diapause, apparency and evaluating conservation status: anomalies from the Australian butterflies. - J. Insect Conserv. 12: 81-85.

SunOSE T. 1978: Studies on extended diapause in Hasegawaia sasacola Monzen (Diptera, Cecidomyiidae) and its parasites. - Kontyu 46: 400-415.

Tauber M.J., Tauber C.A. \& Masaki S. 1986: Seasonal Adaptations of Insects. Oxford University Press, New York, 411 pp.

Templado J. 1981: Diapausa y voltinismo en Euchloe ausonia crameri Butler. - Eos 57: 273-277.

Thomas C.D. \& Mallorie H.C. 1985: Rarity, species richness and conservation: butterflies of the Atlas mountains in Morocco. Biol. Conserv. 33: 95-117.

Tielbörger K., Petrů M. \& Lampei C. 2012: Bet-hedging germination in annual plants: A sound empirical test of the theoretical foundations. - Oikos 121: 1860-1868.

Van Swahy C., Cuttelod A., Collins S., Maes D., López Munguira M., Šašić M., Settele J., Verovnik R., Verstrael T., Warren M., Wiemers M. \& Wynhof I. 2010: European Red List of Butterfies. Publications Office of the European Union, Luxembourg, $58 \mathrm{pp}$.

WIKLUND C. 2003: Sexual selection and the evolution of butterfly mating systems. In Boggs C.L, Watt B.W. \& Ehrlich P.R. (eds): Butterflies - Ecology and Evolution Taking Flight. Chicago University Press, Chicago, pp. 67-90.

Xu W.H., Sato Y., Ikeda M. \& Yamashita O. 1995: Stage-dependent and temperature-controlled expression of the gene encoding the precursor protein of diapause hormone and pheromone biosynthesis activating neuropeptide in the silkworm, Bombyx mori. - J. Biol. Chem. 270: 3804-3808.

Zhang T.Y., Sun J.S., Zhang Q.R., Xu J., Jiang R.J. \& Xu W.H. 2004: The diapause hormone-pheromone biosynthesis activating neuropeptide gene of Helicoverpa armigera encodes multiple peptides that break, rather than induce, diapause. $-J$. Insect Physiol. 50: 547-554.

Zhang Q., Zdarek J., Nachman R.J. \& Denlinger D.L. 2008: Diapause hormone in the corn earworm, Helicoverpa zea: Optimum temperature for activity, structure-activity relationships, and efficacy in accelerating flesh fly pupation. - Peptides 29: 196-205.

Received October 14, 2016; revised and accepted February 3, 2017 Published online March 14, 2017 